\title{
Natural disturbances and interannual variability of coral reef communities on the outer slope of Tiahura (Moorea, French Polynesia): 1991 to 1997
}

\author{
Mehdi Adjeroud*, David Augustin, René Galzin, Bernard Salvat \\ Ecole Pratique des Hautes Etudes, ESA CNRS 8046, Université de Perpignan, 66860 Perpignan Cedex, France, and \\ Centre de Recherches Insulaires et Observatoire de l'Environnement, BP 1013, Moorea, French Polynesia
}

\begin{abstract}
We analysed the interannual variability of the major reef communities (algae, corals and fishes) on the outer slope of the Tiahura sector on Moorea Island between 1991 and 1997, and examined the impacts of natural disturbances on these communities. Patterns of temporal variation and the response to natural perturbations were clearly different among the taxa examined. A sharp decrease in the percent cover of branching corals (Pocillopora and Acropora) followed cyclonic and bleaching events that occurred in 1991. After 1993, a slight increase in coral cover values was recorded, and can be interpreted as a sign of recovery. Despite a similar proportion of bleached colonies at the beginning of bleaching events in 1991 and 1994, the bleaching in 1994 had no significant impact on coral cover. This result demonstrates the importance of understanding the ecological history of reefs (i.e. the chronology of disturbances) in interpreting the specific impacts of a particular disturbance. The decline in coral cover was accompanied by an increase in the percent cover of turf algae, but surprisingly, the percent cover of macroalgae did not show any significant temporal variation during the $7 \mathrm{yr}$ period. Thus, the decrease in the percent cover of corals, which opens up new substrate, does not always result in an increase in macroalgal cover. The temporal variation of the fish community was mainly characterized by (1) the high variability in the recruitment of juveniles, with a peak in 1991; (2) the slight increase in the density of adult species; and (3) the decrease in the density of corallivorous chaetodontid fishes from 1991 to 1994 . Since corals were the only taxon directly affected by natural disturbances, they were consequently the cause of the indirect effects of these disturbances (i.e. increase in turf algae and decrease in chaetodontid fishes), and can therefore be regarded as the 'key component' of the outer slope reef communities in Moorea.
\end{abstract}

KEY WORDS: Coral reefs $\cdot$ Temporal variability $\cdot$ Natural disturbances $\cdot$ Partial canonical correspondence analysis · French Polynesia

Resale or republication not permitted without written consent of the publisher

\section{INTRODUCTION}

The temporal variation of communities is governed by a variety of interacting physical, biological and anthropogenic processes that vary in frequency, intensity and spatial scale (Levin 1992, Karlson \& Hurd 1993). Recent research in community ecology has also recognized the important contribution of disturbances

*E-mail: adjeroud@univ-perp.fr (i.e. major historical events) on the spatio-temporal structure of communities (Connell 1978, Grigg 1983, Sousa 1984, Hughes 1989, 1994, Done 1992a,b, Witman 1992, Karlson \& Hurd 1993, Connell 1997, Hughes \& Connell 1999). The variability of coral reef ecosystems over a time scale of years or decades has become increasingly documented (Dustan \& Halas 1987, Done 1992b, Liddell \& Ohlhorst 1992, Witman 1992, Bythell et al. 1993, Dollar \& Tribble 1993, Bak \& Nieuwland 1995, Shulman \& Robertson 1996, Augustin et al. 1997, Connell 1997, Connell et al. 1997, Ninio et al. 2000). 
The major disturbances experienced by coral reefs are cyclones (Woodley et al. 1981, Harmelin-Vivien 1994), coral-bleaching events (Salvat 1992, Hoegh-Guldberg \& Salvat 1995, Hoegh-Guldberg 1999, Wilkinson et al. 1999), outbreaks of predators, particularly the starfish Acanthaster planci in the tropical Pacific (Moran 1986, Endean \& Cameron 1990) and mass mortalities of keystone species, such as the sea urchin Diadema antillarum in the tropical western Atlantic (Lessios et al. 1984, Hughes 1994). Because disturbances and also biotic and abiotic factors can co-vary in a manner that makes it difficult to decipher their relative contributions (Quinn \& Dunham 1983, Karlson \& Hurd 1993, Adjeroud 1997), a difficult challenge for ecologists is to discriminate the relative contribution of these factors in the control of community structure (Hatcher et al. 1989) as well as to distinguish the natural disturbances from the man-induced ones (Brown 1987, Dahl \& Salvat 1988, Grigg \& Dollar 1990).

The research program ATPP (Agencement Temporel des Populations et des Peuplements) was initiated in 1990 on Moorea Island, French Polynesia, to analyze the dynamics of reef communities (Galzin et al. 1993, Augustin 1998). As a contribution to this program, the present study aimed to (1) examine the interannual variability of the major reef communities (algae, corals and fishes) on the outer slope of the Tiahura sector between 1991 and 1997; and (2) determine the impacts of natural disturbances on these communities. During the study period, the outer slope of Tiahura has experienced 2 coral-bleaching events (March 1991 and March 1994) and the cyclone Wasa (December 1991). The present study focused exclusively on the impacts of natural disturbances. In fact, man-induced disturbances, such as dredging, construction activities, sewage discharges and runoff, which have important impacts on fringing reef communities around Moorea, have a negligible impact on the outer slope (Salvat et al. 1979, Augustin et al. 1997, Augustin 1998).

A holistic approach to the temporal variability of reef communities and the impacts of natural disturbances in French Polynesia is timely for a number of reasons. First, whereas our knowledge of the spatial patterns of macrobenthic (Adjeroud 1997) and fish (Galzin 1987a, Galzin \& Legendre 1987) communities has greatly improved in the last decade, little information is avalaible on their interannual variability on the outer slope (Galzin 1987b, Augustin et al. 1997). This lack of knowledge makes it difficult to tackle questions related to the functioning of coral reef ecosystems. Second, previous studies on the spatial patterns have revealed several characteristics of French Polynesian reefs, such as strong gradients in species richness and abundance at a small spatial scale (Adjeroud 1997). Therefore, a study on the interannual variability of French Polynesian reefs can provide insights into the temporal patterns of reef communities in general and the role that natural disturbances may play in causing these patterns.

\section{MATERIALS AND METHODS}

Study area. Moorea Island $\left(17^{\circ} 30^{\prime} \mathrm{S}, 149^{\circ} 50^{\prime} \mathrm{W}\right)$ is located $25 \mathrm{~km}$ to the northwest of Tahiti. It comprises $134 \mathrm{~km}^{2}$ of land, $49 \mathrm{~km}^{2}$ of reefs and lagoon, and has a circumference of $61 \mathrm{~km}$ (Fig. 1). The island is surrounded by a narrow coral belt of $2 \mathrm{~km}$ maximum width (Galzin \& Pointier 1985). The coral reef ecosystem can be divided into 3 major reef habitats: fringing reef; barrier reef flat (separated from the fringing reef by a narrow sandy channel); and outer slope (separated from the barrier reef flat by the reef front). Approximately 10000 people live on Moorea. The tides are semi-diurnal with an amplitude rarely exceeding $40 \mathrm{~cm}$. Tropical cyclones are rare in French Polynesia; major ones occurred in 1906 and during 3 El Niño events: 1982 to 1983, 1991 and 1997 to 1998. Additionally, major coral-bleaching events in French Polynesia have been reported in 1983, 1984, 1987, 1991, 1994 and 1998 (Salvat 1992, Hoegh-Guldberg \& Salvat 1995, Augustin et al. 1997, Mumby et al. 2001). In Moorea, bleaching events caused by thermal stress

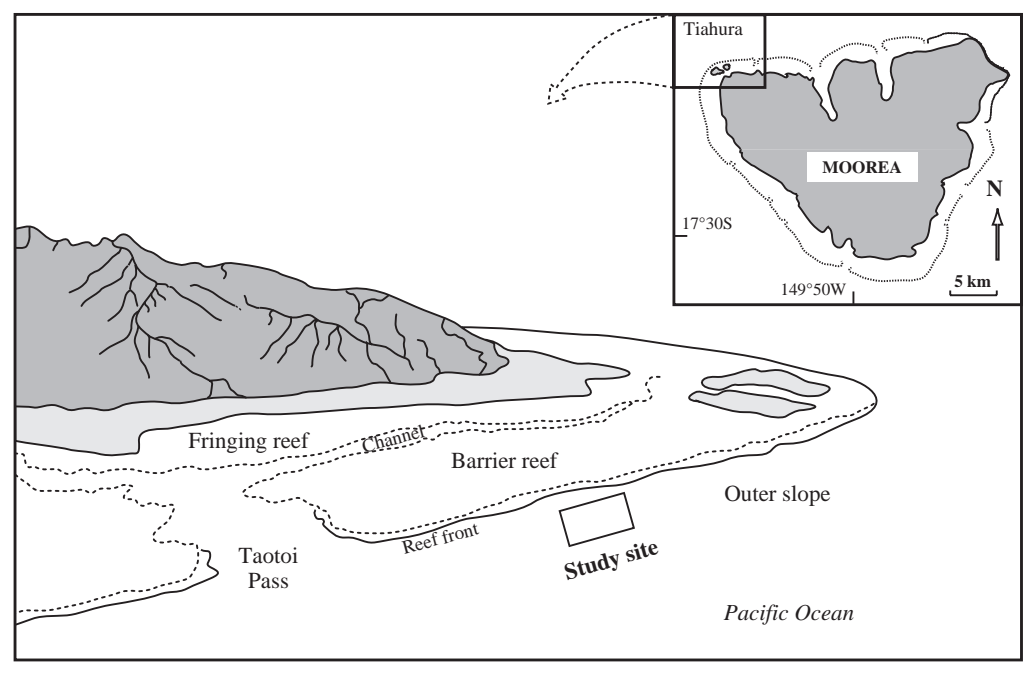

Fig. 1. Map of the Tiahura sector on the NW part of Moorea Island, French Polynesia, showing the location of the study site at $12 \mathrm{~m}$ depth on the outer slope 
$\downarrow \downarrow \downarrow \downarrow \downarrow$

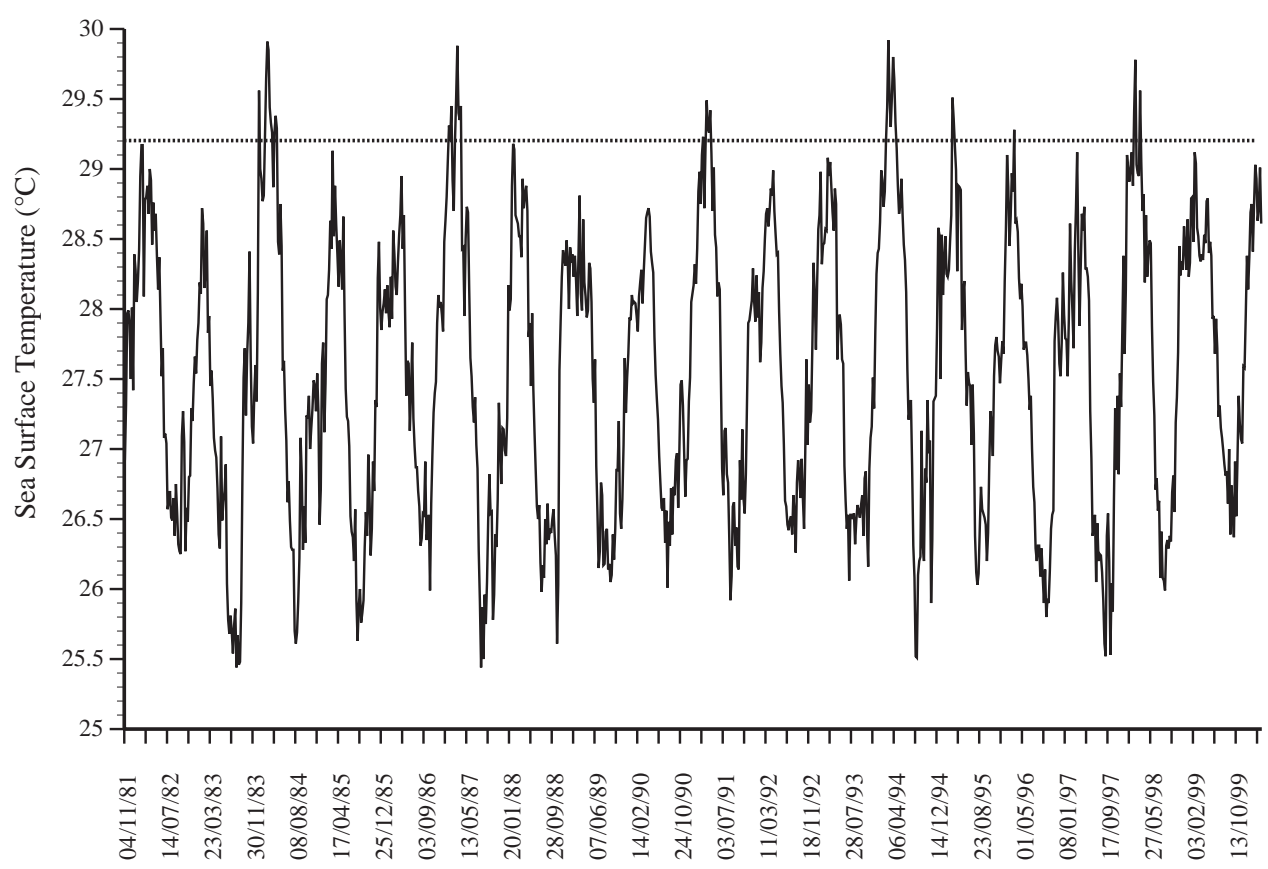

Fig. 2. Weekly sea surface temperature data for Tahiti $\left(17.5^{\circ} \mathrm{S}\right.$, $\left.149.5^{\circ} \mathrm{W}\right)$. Dates given as $\mathrm{dd} / \mathrm{mm} / \mathrm{yy}$. IGOSS-nmc data courtesy of the Lamont-Doherty Climate Center at Columbia University (http://rainbow.ldgo.columbia. edu/). Arrows indicate bleaching events caused by thermal stress reported in Moorea $(1984,1987$, 1991, 1994). Horizontal dotted line indicates the thermal threshold for Tahiti $\left(29.2^{\circ} \mathrm{C}\right.$; Hoegh-Guldberg 1999) were reported in 1984, 1987, 1991 and 1994, and corresponded to periods when sea surface temperatures (SSTs) rose above $29.2^{\circ} \mathrm{C}$ (i.e. thermal thresholds; Hoegh-Guldberg 1999; Fig. 2). Acanthaster planci outbreaks occurred in 1982, 1984 and 1987 (Faure 1989). Since then, no outbreaks have been observed, possibly because of the starfish-collecting campaigns organized by French Polynesian authorities.

The study site is located in the Tiahura sector on the northwestern part of the island (Fig. 1). At Tiahura, the fringing reef is approximately $250 \mathrm{~m}$ wide and 0.5 to $1.5 \mathrm{~m}$ deep. The channel, which is about $80 \mathrm{~m}$ wide and $8 \mathrm{~m}$ deep, directs water flowing over the barrier reef back to the ocean through the Taotoi Pass (Galzin \& Pointier 1985, Wolanski et al. 1993). The barrier reef is $490 \mathrm{~m}$ wide and begins near the channel in a zone of fine coral sand where the water depth does not exceed $2.5 \mathrm{~m}$. This area is adjacent to a reef flat with sparsely distributed coral patches, increasing in number towards the ocean. The outer slope down to $7 \mathrm{~m}$ is a furrowed and gently sloping platform about $80 \mathrm{~m}$ wide. Beyond that depth, the inclination of the slope increases and the platform is replaced by a spur and groove system which ends at $15 \mathrm{~m}$ depth in a $15 \mathrm{~m}$ wide sedimentary basin, parallel to the reef front. A buttresses and valleys zone extends from 15 to $30 \mathrm{~m}$ deep and is followed by a slightly inclined sandy slope. More detailed morphological descriptions of the outer slope were given by Jaubert et al. (1976) and Vigliola et al. (1996).
Sampling strategy. This study focused on the 3 dominant reef communities of the French Polynesian outer slope: algae (macroalgae, turf algae and encrusting coralline algae), cnidarians (including hard and soft corals and Millepora, herein classified as corals) and fishes. For corals, only the most conspicuous colonies of more than $1 \mathrm{~cm}$ and visible without removing rocks were recorded. For fish communities, we distinguished the juveniles (i.e. total length < size upon reaching sexual maturity) from the adults. Data were collected in 8 rectangular quadrats of $100 \mathrm{~m}^{2}$ each $(25 \mathrm{~m} \times 4 \mathrm{~m})$ placed at $12 \mathrm{~m}$ depth on the outer slope. Quadrats were laid by pairs, placed contiguously along their length. Four of these quadrats were approximately perpendicular to the reef front, while the remaining ones were at a $45^{\circ}$ angle with the reef front. A linear transect of $25 \mathrm{~m}$ was established at the intersection of each of the 4 paired quadrats.

Fish sampling was carried out within the 8 quadrats. At each quadrat, qualitative (i.e. presence or absence of fish species) and quantitative (densities) observations were made during 2 passages. During the first passage, 4 stops were made along the $25 \mathrm{~m}$ length of the quadrat, including the start and the end of the quadrat. During these 4 stops, elusive species such as Scaridae, Labridae, Balistidae and Acanthuridae were recorded. Sedentary and cryptic species, such as Serranidae, Pomacentridae and Holocentridae, were recorded during a slow swim between the stops. For species that were particularly abundant, such as Ptero- 
caesio tile, Chromis iomelas, C. vanderbilti and Dascyllus flavicaudus, densities were estimated to the nearest 10 . The second passage focused exclusively on the surgeonfish species, Ctenochaetus striatus.

The percent cover of algae (macroalgae, turf algae and encrusting coralline algae) and corals was recorded along the 4 transects of $25 \mathrm{~m}$. We used the Point Intercept Transect Method (Loya 1978), with points placed every $0.25 \mathrm{~m}$, to estimate cover. Macroalgae and fishes were identified to the species level, while corals were identified to the generic level. Data were collected once a year from 1991 to 1997. Observations were made by the same person (fishes: R.G.; corals and algae: B.S.) during the same period (March to April) and between the same hours (08:00 and 12:00 h) around the time of the full moon. This reduced the diurnal, lunar and seasonal natural variations, which can be pronounced for fishes and macroalgae (Galzin 1987b, Payri 1987).

Data analysis. Two types of analyses were performed. First, we examined the interannual variability of synthetic variables (species richness, density and cover). The significance of the interannual variability of these variables was evaluated using the nonparametric test of Friedman, because of the absence of normality in the data set, and because these data were not independent (paired quadrats and successive years; Sokal \& Rohlf 1995). When a significant interannual variability was detected, the Wilcoxon test was a posteriori used to compare values of 2 differents years (Sokal \& Rohlf 1995). Second, we used the canonical correspondence analysis (CCA) to test the interannual variability of the species data matrix.

CCA was developed by ter Braak (1986, 1987, 1988) and is an increasingly popular method for multivariate analysis of ecological community data (Palmer 1993, McCune 1997, Legendre \& Legendre 1998). A further and very interesting development of this analysis allows partial CCA, where the computations are made after removing, by multiple linear regression, the effects of undesired covariables (ter Braak 1988, Legendre 1990). We used partial CCA to separate the interannual variability from the spatial variation. Partial CCA was carried out on the fish community data set only. Since we focused on the most conspicuous macrobenthic species, a small number of macroalgal and coral species were recorded, which is not compatible with the use of multivariate analyses. Three matrices were used in the computations: (1) the species data matrix (fish species composition and densities); (2) the covariable matrix (binary data which codify the different quadrats); and (3) the variable matrix (binary data which codify the different years). In the ordination diagram, equiprobability ellipses were drawn to facilitate the interpretation of the results. When 2 ellipses (rep- resenting $95 \%$ of the quadrats of 1 year) did not overlap, the species composition was then considered to be distinct. Fish species were not represented in the ordination plots because they were too numerous and would greatly reduce the legibility of the plots. Additional details on how to interpret CCA and partial CCA results are given in ter Braak (1986), Borcard et al. (1992), Palmer (1993) and Legendre \& Legendre (1998). The complete list of fish, coral and macroalgal species is available from the authors. Partial CCA was carried out using the CANOCO software (ter Braak 1992).

\section{RESULTS}

\section{Corals and algae}

A significant interannual variability in the coral cover was observed (Friedman test, $\mathrm{p}=0.02$ ). Between 1991 and 1992, a sharp decrease in total coral cover was recorded (from 51.0 to $24.2 \%$ ), whereas values increased slightly from 1993 to 1997 (Fig. 3). The decrease was mainly observed for the genera Acropora, for which cover dropped from $11.5 \%$ in 1991 to $2.5 \%$ in 1992. Similarly for Montipora, from $7.2 \%$ in 1991 to $2.7 \%$ in 1992, and for Pocillopora, from $25.0 \%$ in 1991 to $10.5 \%$ in 1992 . The cover of all other genera was stable and did not show any significant variation during the $7 \mathrm{yr}$ period. Among the 10 coral genera observed in the transects, Pocillopora, Acropora, Porites and Montipora accounted for more than $85 \%$ of the coral cover. The contribution of these 4 genera to the coral cover was relatively similar among the years (between 85 and $93 \%$ ). The number of coral colonies did not show any significant interannual variability (Friedman test, $\mathrm{p}=0.12$ ).

The percent cover of algae was dominated by turf and encrusting coralline algae (ECA), whereas only 1 macroalgal species, Turbinaria ornata, was recorded with a low cover $(<1.2 \%$; Fig. 4$)$. A decrease in ECA cover was observed between 1991 and 1994. However, the interannual variability of macroalgae and ECA cover was low and not significant (Friedman test, $\mathrm{p}=$ 0.15 and 0.09 , respectively). In contrast, turf cover increased between 1991 and 1994, with a 2-fold increase between 1991 and 1992 (from 16.2 to $33.7 \%$; Wilcoxon test, $\mathrm{p}=0.03$ ). Despite a slight decrease from 1994 to 1995, turf cover remained relatively high between 1995 and 1997.

\section{Fishes}

A total of 135 fish species (27 families), including 132 species of adult fishes and 75 species of juveniles, was 

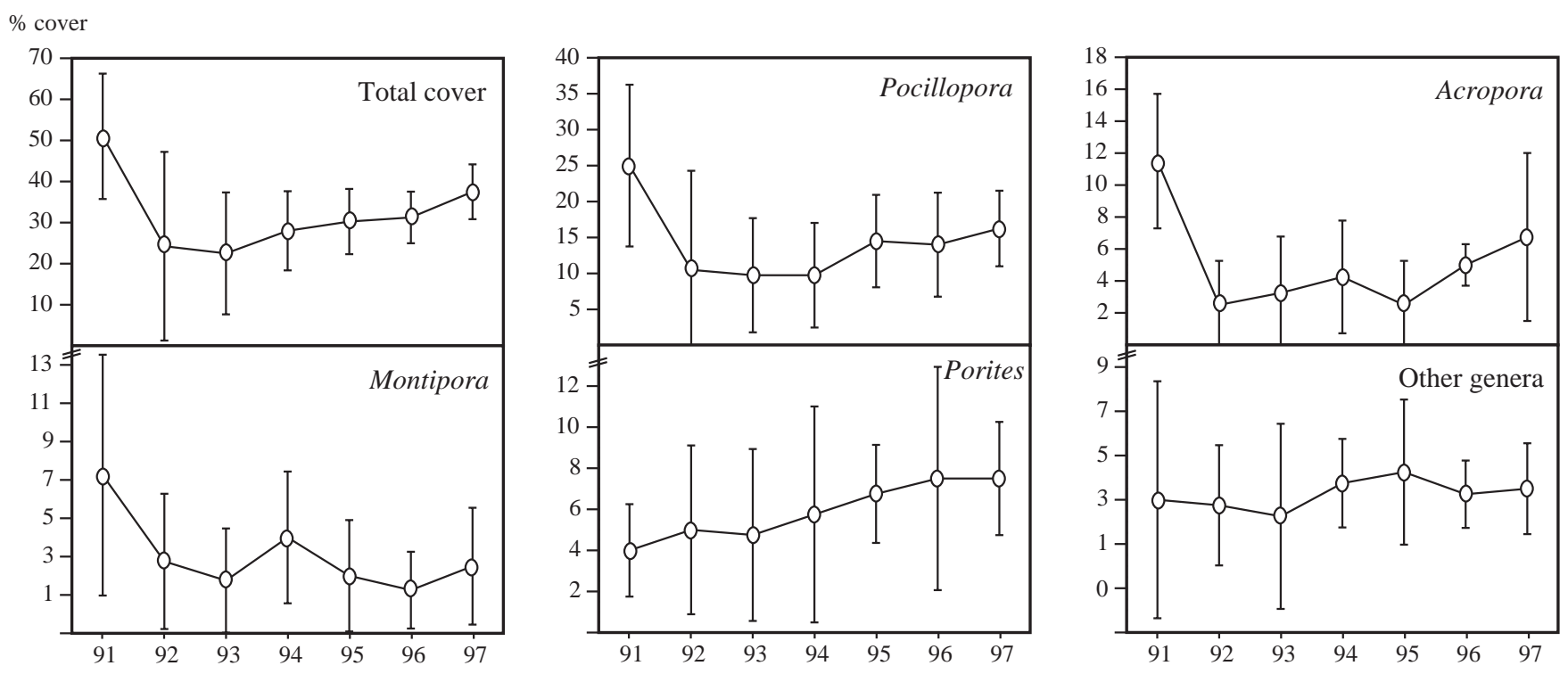

Fig. 3. Interannual variation in the percent cover of corals. Bars represent $95 \%$ confidence intervals

recorded from 1991 to 1997 . The density of adults increased from 1991 to 1997 (263 to 549 ind. per $100 \mathrm{~m}^{2}$; $\mathrm{p}<0.001$; Fig. 5), and was mainly due to the significant increase of Paracirrhites arcatus, Centropyge loriculus, Pseudocheilinus octotaenia, Ctenochaetus strigosus and Cantherhines pardalis (Friedman test, p < 0.05). Species richness of adult fishes was also variable among the years (Friedman test, p = 0.0039), with higher values in 1996 and 1997. Among adult fishes, the total density of obligate corallivores from the chaetodontid family (5 species) decreased from 1991 to 1994, but was followed by a return to initial values in 1995 (Friedman test, $\mathrm{p}=0.0013$; Fig. 6).

Concerning juvenile fishes, the density and species richness was highly variable between years (Fig. 5). A high recruitment of 3 species, Ctenochaetus striatus, Chromis vanderbilti and Scarus sordidus, which accounted for 34,31 and $5 \%$ of the total density of juveniles respectively, was observed in 1991. In contrast, the density and species richness of juveniles were low in 1996 and 1997. It should be noted that the peak of $C$. striatus juveniles in 1991 (75 ind. per $100 \mathrm{~m}^{2}$ ) was not observed the following years. This characteristic (i.e. high density of juveniles recorded in a single year and very low values the other years) was also observed for Acanthurus bleekeri and Chaetodon reticulatus in 1991 and for Naso lituratus in 1994.

Two separate partial canonical correspondence analyses were performed: (1) with the adult data; and (2) with the juvenile data (Fig. 7). These partial CCA were statistically significant (Monte-Carlo permutation tests, $p=0.001$ ), indicating the existence of an interannual variability in the qualitative (species composition) and quantitative (densities of each species) aspects of the fish community. The adult fish assemblage that we recorded in 1991 was clearly distinct from that of the other years. In 1992, 1993, and 1996, the assemblage was also distinct, but to a lesser degree compared to 1991. In contrast, no significant difference in the fish assemblage was observed between 1994, 1995 and
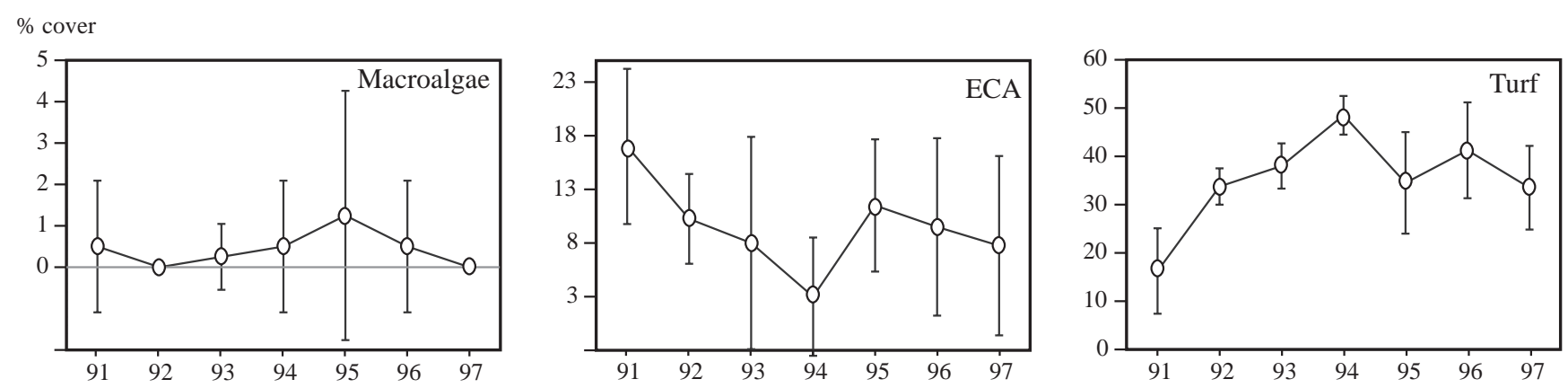

Fig. 4. Interannual variation in the percent cover of macroalgae, encrusting coralline algae (ECA) and turf algae. Bars represent $95 \%$ confidence intervals 
Adults

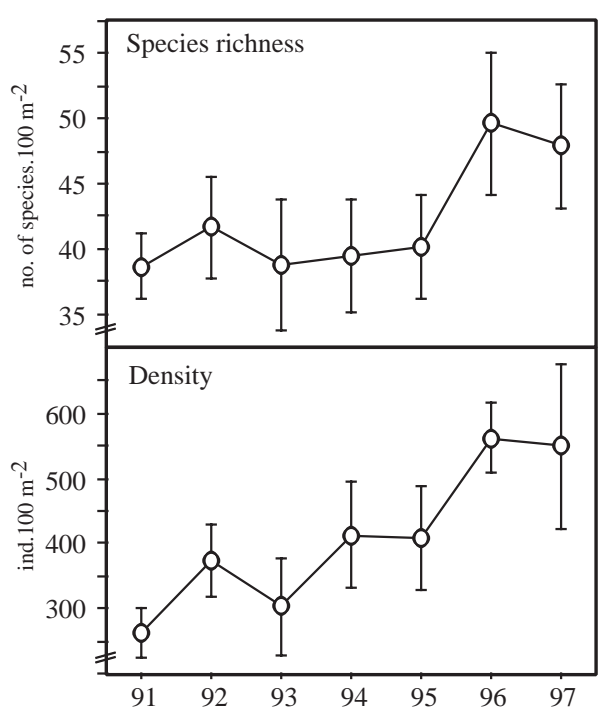

Juveniles

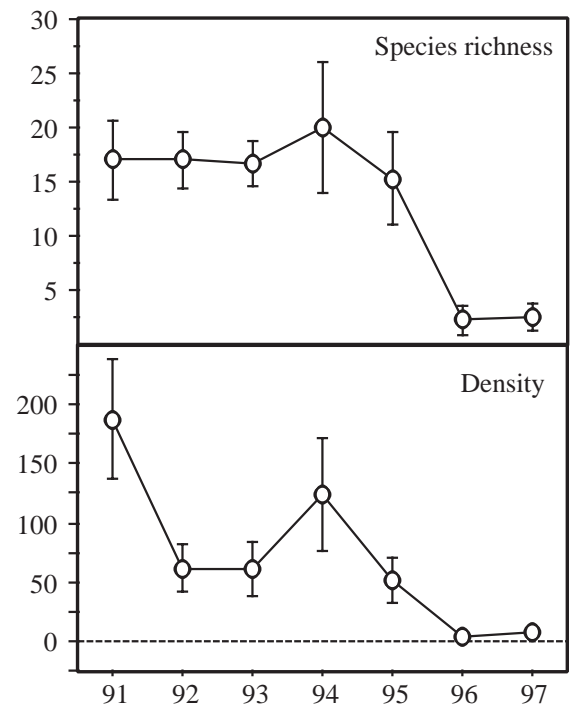

Fig. 5. Interannual variation in the species richness and density of fishes. Data are given for adults and juveniles. Bars represent $95 \%$ confidence intervals

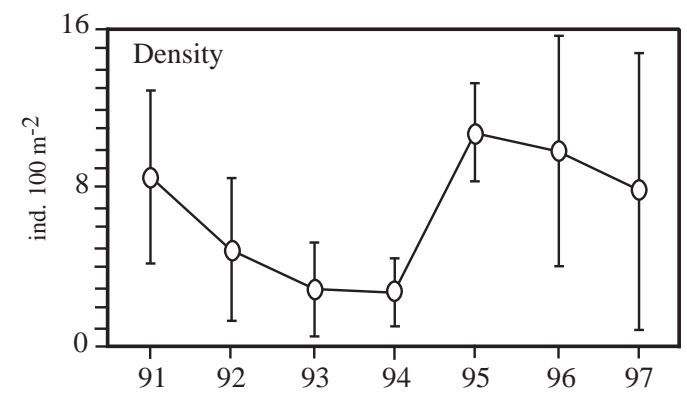

Fig. 6. Interannual variation in the density of obligate corallivorous chaetodontid fishes (5 species recorded in the present study). Bars represent $95 \%$ confidence intervals

Adults

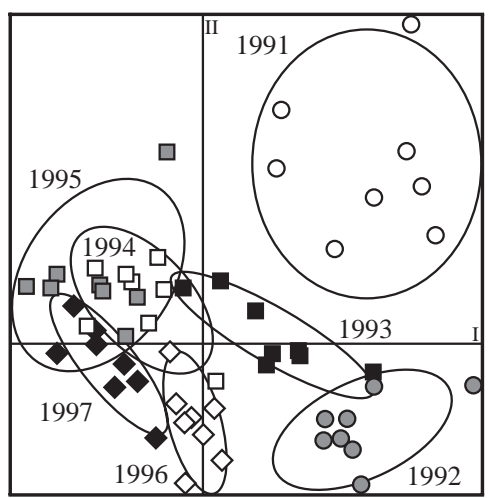

Fig. 7. Plots of the partial canonical correspondence analyses performed on the adult and the juvenile fish community data. Position of quadrats and years along the first 2 axes is given. Equiprobability ellipses, representing $95 \%$ of the quadrats of $1 \mathrm{yr}$, are drawn. When 2 ellipses did not overlap, the assemblages of the 2 yr were considered to be distinct. Conversely, 2 overlapping ellipses indicated that the assemblages of the $2 \mathrm{yr}$ were similar to each other
1997. In 1991, the assemblage was characterized by the absence of the adult Scarus psittacus, and high densities of Lutjanus kasmira and Chaetodon ulietensis adults, whereas in 1992, it was characterized by the high densities of Dascyllus trimaculatus and Scarus rubroviolaceus adults. The high density of L. kasmira associated with the low density of Scarus oviceps and the absence of $S$. psittacus explained the distinction of the assemblage in 1993. The distinction between the assemblage in 1996 and the ones in 1994, 1995 and 1997 was less pronounced, and was due to small differences in the abundance of species such as Aphareus furca, Centropyge loriculus, Chromis iomelas, Chromis margaritifer and Dascyllus flavicaudus. The juvenile fish assemblages showed less difference between years than the adults, with only the 1991 assemblage being distinct. The high densities of juvenile Acanthurus bleekeri and Ctenochaetus striatus explained the distinction of the juvenile fish assemblage in 1991.

\section{DISCUSSION}

The results of this survey clearly showed that the patterns of temporal variation of the outer slope communities at Tiahura and their response to natural disturbances were different among the taxa examined. No significant changes were observed for macroalgae and encrusting coralline algae, whereas corals, turf algae and fishes showed significant interannual variation. 


\section{Corals and algae}

A severe decline in coral cover on the outer slope of Tiahura followed the bleaching event which started in March 1991 and the cyclone Wasa in December 1991. Coral communities of outer slopes in French Polynesia are dominated by the branching genera Acropora and Pocillopora, which are particularly vulnerable to breakage and fragmentation (Randall \& Eldredge 1977, Highsmith et al. 1980, Woodley et al. 1981, Harmelin-Vivien 1994) and which are the most affected by bleaching events (Salvat 1992, Gleason 1993, Hoegh-Guldberg \& Salvat 1995). Pocillopora and Acropora suffered 50 and $10 \%$ mortality respectively on outer slopes at Tiahura as a result of the bleaching event in 1991 (Salvat 1992). The cyclone and the bleaching event in 1991 had a lower impact on the coral community of the barrier reef flat, which is dominated by large colonies of massive Porites that are particularly resistant to both bleaching $(0 \%$ mortality; Salvat 1992) and cyclones (Augustin 1998).

In contrast to 1991, the bleaching event in March 1994 did not have an important impact on coral cover of the outer slope. In fact, the magnitude of the event (i.e. the proportion of bleached colonies) and the order of susceptibility of coral genera were similar in 1991 and 1994 (Gleason 1993, Hoegh-Guldberg \& Salvat 1995), whereas the mortality at the end of the event was greatly reduced in 1994, explaining why the coral cover did not decrease between 1994 and 1995. This observation illustrates the fact that it is important when considering the impact of bleaching events to distinguish between the proportion of affected colonies at the beginning of the event (i.e. their susceptibility, which depends to a large extent on the intensity and duration of the stress) and the mortality of coral colonies at the end of the event, which results in the decrease of coral cover (Salvat 1992, Gleason 1993). Our results suggest that there is no direct relationship between the proportion of bleached colonies and the mortality at the end of the event, as bleached colonies have the capacity to recover (Williams \& BunkleyWilliams 1990, Gleason 1993). In the present case, another possible explanation of the low mortality following the bleaching event in 1994 is that most of the colonies in place in 1994 were those that survived the 1991 event or were young recruits derived from those colonies. One may assume that these coral colonies and/or their endosymbiotic zooxanthellae were phenotypically (acclimation) and possibly genotypically (adaptation) resistant to bleaching events (Rowan et al. 1997, Hoegh-Guldberg 1999). The fact that the degree of bleaching varies among neighboring colonies of the same species also suggests a large influence of genotypic and microhabitat variation in susceptibility (Har- riott 1985, Gleason 1993). This acclimation and/or adaptation of coral colonies may also explain the absence of a bleaching event around Moorea in 1998 (pers. obs.), despite a rise of SSTs above the thermal threshold (Fig. 2).

The decrease in total coral cover from 1991 to 1993 was followed by a slight increase recorded until 1997 (51.0\% in $1991,22.5 \%$ in 1993 and $37.5 \%$ in 1997). This tendency can be interpreted as a sign of a rapid recovery (resilience) (Connell 1997). Rates of recovery following disturbances vary greatly among corals reefs (Pearson 1981). In St. Croix, US Virgin Islands (Bythell et al. 1993), and in the Florida Keys (Shinn 1976) reefs which have been severely affected by hurricanes have recovered completely within $6 \mathrm{yr}$, whereas Dollar \& Tribble (1993) estimated that the recovery of Hawaiian reefs affected by storm disturbances would take 40 to $70 \mathrm{yr}$. In a review on the nature of the response of corals to disturbances, Connell (1997) distinguished 3 categories of reefs from a set of 67 examples: (1) those where coral cover did not decline ( $29 \%$ of the 67 examples, with fewer declines in the Indo-Pacific than in the western Atlantic); (2) those where coral declined and recovered (29\%, all in the Indo-Pacific); and (3) those where coral declined but did not recover $(42 \%)$. In fact, recovery depends to a large extent on the type of disturbance causing the original decline (i.e. its intensity and duration; Connell 1997) and on the history of the reef (i.e. the chronology of disturbances; Witman 1992, Hughes \& Connell 1999). Coral cover recovered after $69 \%$ of the acute, short-term disturbances, but after only $27 \%$ of the chronic, long-term ones (Connell 1997). According to the classification of Connell (1997), the coral reef community of the outer slope at Tiahura belongs to the second category.

The decrease in coral cover from 1991 to 1993 on the Tiahura outer slope was accompanied by an increase in the percent cover of turf algae. This indirect relationship is common in coral reef ecosystems (Done 1992a,b, Shulman \& Robertson 1996). Filamentous algal turfs are typically the first colonists of reef substrate denuded after storms (Pearson 1981, Rogers et al. 1982), bleaching events (Glynn 1983), Acanthaster outbreaks (Endean \& Cameron 1990) and anthropogenic perturbations such as ship groundings (Smith 1988).

On the other hand, the percent cover of macroalgae did not show any significant interannual variability, with very low values from 1991 to 1997. Despite the fact that macroalgal cover is generally less than $10 \%$ on outer reef slopes around Moorea (Adjeroud 1997), this relative stability is surprising for a number of reasons. First, macroalgal biomass and cover generally have pronounced seasonal and interannual variations in coral reef ecosystems (Payri 1987). Second, declines in coral cover, caused by natural or anthropogenic dis- 
turbances which open up new substrate for colonization, are generally followed by an increase in filamentous algae as well as macroalgae (Rogers et al. 1991, Shulman \& Robertson 1996). Coral to algal phase transitions have been observed in several coral reefs around the world (see Done 1992a). However, the absence of immediate effects of the cyclone Wasa on macroalgal cover on the outer slope of Tiahura cannot be clearly demonstrated because the 4 mo period separating the cyclone (December 1991) and the 1992 survey (April) could have masked some short-term effects. Finally, the relative stability of macroalgal cover in Tiahura was restricted to the outer slope, since on the fringing and barrier reef flats, where diversity and biomass of macroalgae are higher (Adjeroud 1997), a significant interannual and long-term variability was observed, with an increase in their percent cover (Augustin et al. 1997, Augustin 1998). Our results on the outer slope of Tiahura suggest that the increased availability of denuded substrate is not sufficient to cause an increase in macroalgal cover. Synergetic effects with other factors, such as water eutrophication and reduction of herbivorous density, are probably necessary for the establishment of the macroalgal bloom that might follow a coral decline (Hughes 1994, Hughes et al. 1999).

\section{Fishes}

The temporal variation of the fish community from 1991 to 1997 was characterized by the high variability in the recruitment of juveniles fishes with a peak in 1991 and by the slight increase in the density of adult fishes. The species composition and the relative abundance of each species were different among years. The interannual variability of the fish community on the outer slope of Tiahura complements the daily, monthly and seasonal variations in fish communities that were reported for Moorea (Galzin 1985, 1987b).

No direct impacts of the cyclone Wasa in 1991 were observed in the fish community on the outer slope of Tiahura. Direct effects of cyclones on reef fish communities vary widely with the intensity and the range of destruction caused to coral communities (HarmelinVivien 1994). Previous studies have demonstrated little direct influence (Letourneur 1991), whereas others have reported mass mortality of fishes (Pfeffer \& Tribble 1985). In fact, a large number of fish species are able to escape the negative effects of a cyclone by moving to deeper zones during the period of the event (Harmelin-Vivien 1994). In contrast, there was probably an indirect effect of the cyclone Wasa and the 1991 bleaching events for 1 component of the fish community, the Chaetodontidae. The decline of coral cover, mainly due to the mortality of the branching genera Acropora and Pocillopora, was accompanied by a decrease in the density of corallivorous chaetodontid fishes from 1991 to 1994. Moreover, the return of chaetodontid densities to initial values in 1995 is possibly related to the slight increase in coral cover which started in 1993. These results suggest that the exclusive coral feeders were the most affected by the decrease in branching coral colonies, as was previously demonstrated in Moorea by Bouchon-Navaro et al. (1985). The relationship between chaetodontids and corals is a common feature in coral reef ecosystems and has been well documented (Reese 1977, 1981, Bell \& Galzin 1984, Bouchon-Navaro et al. 1985, Findley \& Findley 1985, Williams 1986, Bouchon-Navaro \& Bouchon 1989, Roberts et al. 1992, Cox 1994, Cadoret et al. 1995, 1999, Syms 1998). The Chaetodontidae are 1 of the few members of reef fish assemblages that show consistent responses to the loss of live coral cover. This has been documented in experimental studies at small spatial scales (Lewis 1997, 1998, Syms 1998) and at whole reef scales following disturbances caused by crown of thorns starfish (Williams 1986).

Our data clearly demonstrated that: (1) the density of adult fishes increased slightly from 1991 to 1997; (2) 1991 was a very good year for fish recruitment as there were a lot of juveniles inside the area; and (3) there was a slight decrease in the density of chaetodontids from 1991 to 1994 and then an increase until 1997. As observed by Sale \& Steel (1989) on the Great Barrier Reef, we may explain these results by the conjunction of the following events. Despite the decrease in coral cover from 1991 to 1993, the density of adult fishes on the whole increased from 1991 to 1993 due to the generally high fish recruitment in 1991. Adult fish density continued to increase after 1993 in parallel with the recovery of the coral cover. The decrease in coral cover after the bleaching in 1991 lasted until 1993, but the decline in chaetodontid density continued until 1994. It is possible that these fishes recruit into specific types of live coral that did not regrow until some years after the bleaching event. This might account for the delay in recovery.

\section{CONCLUSION}

The present study highlights the central role of corals in the structure and function of coral reefs. They were the only taxa directly affected by natural disturbances and consequently were the cause of the indirect effects of these disturbances. It is generally believed that mortality rates following bleaching events are related to the intensity and duration of sea temperature anomalies (see Hoegh-Guldberg 1999). Our re- 
sults do not fit this general rule. The absence of significant impacts of the 1994 bleaching event clearly demonstrates the importance of understanding the ecological history of the reefs (i.e. the chronology of disturbances) in order to interpret the specific impacts of a particular disturbance (Connell 1978, 1997, Grigg \& Dollar 1990, Done 1992a,b, Witman 1992, Hughes 1994, Hughes \& Connell 1999). Several studies have documented an increase in turf and macroalgal covers following man-induced or natural disturbances (Pearson 1981, Rogers et al. 1982, 1991, Glynn 1983, Smith 1988, Endean \& Cameron 1990, Done 1992a,b, Shulman \& Robertson 1996). Our results show for the first time that the decrease in the percent cover of corals, which opens up new substrate, does not always result in an increase in macroalgal cover.

Acknowledgements. This study was carried out within the framework of the program ATPP (ESA CNRS 8046). The authors thank N. Davies, R. Grigg, O. Hoegh-Guldberg, J. Morrissey, M. Pichon and 3 anonymous reviewers for critical comments on the first drafts.

\section{LITERATURE CITED}

Adjeroud M (1997) Factors influencing spatial patterns on coral reefs around Moorea, French Polynesia. Mar Ecol Prog Ser 159:105-119

Augustin D (1998) Variabilité à long terme des peuplements du récif de Tiahura, Moorea, Polynésie française: 1971-1997. PhD thesis, Université Pierre et Marie Curie and Ecole Pratique des Hautes Etudes, Paris

Augustin D, Galzin R, Legendre P, Salvat B (1997) Variation interannuelle des peuplements récifaux du récif-barrière de Tiahura (île de Moorea, Polynésie française). Oceanol Acta 20:743-756

Bak RPM, Nieuwland G (1995) Long-term change in coral communities along depth gradients over leeward reefs in the Netherlands Antilles. Bull Mar Sci 56:609-619

Bell JD, Galzin R (1984) Influence of live coral cover on coralreef fish communities. Mar Ecol Prog Ser 15:265-274

Borcard D, Legendre P, Drapeau P (1992) Partialling out the spatial component of ecological variation. Ecology 73 : 1045-1055

Bouchon-Navaro Y, Bouchon C (1989) Correlations between chaetodontid fishes and coral communities of the Gulf of Aqaba (Red Sea). Environ Biol Fishes 25:47-60

Bouchon-Navaro Y, Bouchon C, Harmelin-Vivien ML (1985) Impact of coral degradation on a chaetodontid fish assemblage (Moorea, French Polynesia). Proc 5th Int Coral Reef Congr, Tahiti 5:427-432

Brown BE (1987) World wide death of corals - natural cyclical events or man-made pollution? Mar Pollut Bull 18:9-13

Bythell JC, Byhtell M, Gladfelter EH (1993) Initial results of a long-term coral reef monitoring program: impact of hurricane Hugo at Buck Island Reef National Monument, St. Croix, U.S. Virgin Islands. J Exp Mar Biol Ecol 172:171-183

Cadoret L, Legendre P, Adjeroud M, Galzin R (1995) Répartition spatiale des Chaetodontidae dans différents secteurs récifaux de l'île de Moorea, Polynésie française. Ecoscience 2:129-140 (in French, English abstract)
Cadoret L, Adjeroud M, Tsuchiya M (1999) Spatial distribution of chaetodontid fish in coral reefs of the Ryukyu Islands, southern Japan. J Mar Biol Assoc UK 79:725-735

Connell JH (1978) Diversity in tropical rain forests and coral reefs. Science 199:1302-1310

Connell JH (1997) Disturbance and recovery of coral assemblages. Proc 8th Int Coral Reef Symp, Panama 1:9-22

Connell JH, Hughes TP, Wallace CC (1997) A 30-year study of coral abundance, recruitment, and disturbance at several scales in space and time. Ecol Monogr 67:461-488

Cox EF (1994) Resource use by corallivorous butterflyfishes (family Chaetodontidae) in Hawaii. Bull Mar Sci 54: 535-545

Dahl AL, Salvat B (1988) Are human impacts, either through traditional or contemporary uses, stabilizing or destabilizing to reef community structure? Proc 6th Int Coral Reef Symp, Townsville 1:63-69

Dollar SJ, Tribble GW (1993) Recurrent storm disturbance and recovery: a long-term study of coral communities in Hawaii. Coral Reefs 12:223-233

Done TJ (1992a) Phase shifts in coral reef communities and their ecological significance. Hydrobiologia 247:121-132

Done TJ (1992b) Constancy and change in some Great Barrier Reef coral communities: 1980-1990. Am Zool 32:655-662

Dustan P, Halas JC (1987) Changes in the reef-coral community of Carysfort Reef, Key Largo, Florida: 1974 to 1982. Coral Reefs 6:91-106

Endean R, Cameron AM (1990) Acanthaster planci populations outbreaks. In: Dubinsky Z (ed) Ecosystems of the world 25: Coral reefs. Elsevier Science Publishers, Amsterdam, p 469-492

Faure G (1989) Degradation of coral reefs at Moorea Island (French Polynesia) by Acanthaster planci. J Coastal Res 5: 295-305

Findley JS, Findley MT (1985) A search for pattern in butterflyfish communities. Am Nat 126:800-816

Galzin R (1985) Spatial and temporal community structure of coral reef fishes in French Polynesia. Proc 5th Int Coral Reef Congr, Tahiti 5:451-455

Galzin R (1987a) Structure of fish communities of French Polynesian coral reefs. I. Spatial scales. Mar Ecol Prog Ser 41:129-136

Galzin R (1987b) Structure of fish communities of French Polynesian coral reefs. II. Temporal scales. Mar Ecol Prog Ser 41:137-145

Galzin R, Legendre P (1987) The fish communities of a coral reef transect. Pac Sci 41:158-165

Galzin R, Pointier JP (1985) Moorea Island, Society Archipelago. Proc 5th Int Coral Reef Congr, Tahiti 1:73-102

Galzin R, Marfin JP, Salvat B (1993) Long-term coral reef monitoring program: heterogeneity of the Tiahura Barrier Reef (Moorea, French Polynesia). Galaxea 11:73-91

Gleason MG (1993) Effects of disturbance on coral communities: bleaching in Moorea, French Polynesia. Coral Reefs 12:193-201

Glynn PW (1983) Extensive 'bleaching' and death of coral reefs on the Pacific coast of Panama. Environ Conserv 10: 149-154

Grigg RW (1983) Community structure, succession and development of coral reefs in Hawaii. Mar Ecol Prog Ser 11: $1-14$

Grigg RW, Dollar SJ (1990) Natural and anthropogenic disturbance on coral reef ecology. In: Dubinsky Z (ed) Ecosystems of the world 25: Coral reefs. Elsevier Science Publishers, Amsterdam, p 439-452

Harmelin-Vivien ML (1994) The effects of storms and cyclones on coral reefs: a review. J Coastal Res 12:211-231 
Harriott VJ (1985) Mortality rates of scleractinian corals before and during a mass bleaching event. Mar Ecol Prog Ser 21:81-88

Hatcher BG, Johannes RE, Robertson AI (1989) Review of research relevant to the conservation of shallow water tropical marine ecosystems. Oceanogr Mar Biol Annu Rev 27:337-414

Highsmith R, Riggs A, D'Antonio C (1980) Survival of hurricane-generated coral fragments and a disturbance model of reef calcification/growth rates. Oecologia 46:322-329

Hoegh-Guldberg O (1999) Climate change, coral bleaching and the future of the world's coral reefs. Mar Freshw Res 50:839-866

Hoegh-Guldberg O, Salvat B (1995) Periodic mass-bleaching and elevated sea temperatures: bleaching of outer reef slope communities in Moorea, French Polynesia. Mar Ecol Prog Ser 121:181-190

Hughes TP (1989) Community structure and diversity of coral reefs: the role of history. Ecology 70:275-279

Hughes TP (1994) Catastrophes, phase shifts and large scale degradation of a Caribbean coral reef. Science 265: $1547-1551$

Hughes TP, Connell JH (1999) Multiple stressors on coral reefs: a long-term perspective. Limnol Oceanogr 44:932-940

Hughes TP, Smant AM, Steneck R, Carpenter R, Miller S (1999) Algal blooms on coral reefs: what are the causes? Limnol Oceanogr 44:1583-1586

Jaubert J, Thomassin B, Vasseur P (1976) Morphologie et étude bionomique préliminaire de la pente externe du récif de Tiahura, île de Moorea (Polynésie française). Cah Pac 19:299-323

Karlson RH, Hurd LE (1993) Disturbance, coral reef communities, and changing ecological paradigms. Coral Reefs 12: 117-125

Legendre P (1990) Quantitative methods and biogeographic analysis. In: Garbary DJ, South RR (eds) Evolutionary biogeography of the marine algae of the North Atlantic. NATO ASI Series, Vol G22. Springer-Verlag, Berlin, p 9-34

Legendre P, Legendre L (1998) Numerical ecology. Elsevier Science Publishers, Amsterdam

Lessios HA, Robertson DR, Cubit JD (1984) Spread of Diadema mass mortality through the Caribbean? Science 226: 335-337

Letourneur Y (1991) Modifications du peuplement de poissons du platier récifal de Saint-Pierre (île de la Réunion, Océan Indien) consécutives au passage du cyclone Firinga. Cybium 15:159-170 (in French, English abstract)

Levin SA (1992) The problem of pattern and scale in ecology. Ecology 73:1943-1967

Lewis AR (1997) Effects of experimental coral disturbance on the structure of fish communities on large patch reefs. Mar Ecol Prog Ser 161:37-50

Lewis AR (1998) Effects of experimental coral disturbance on the population dynamics of fishes on large patch reefs. J Exp Mar Biol Ecol 230:91-110

Liddell WD, Ohlhorst SL (1992) Ten years of disturbances and change on a Jamaican fringing reef. Proc 7 th Int Coral Reef Symp, Guam 1:144-150

Loya Y (1978) Plotless and transect methods. In: Stoddart DR, Johannes RE (eds) Coral reef research methods. UNESCO, Paris, p 197-217

McCune B (1997) Influence of noisy environmental data on canonical correspondence analysis. Ecology 78:2617-2623

Moran PJ (1986) The Acanthaster phenomenon. Oceanogr Mar Biol Annu Rev 24:379-480

Mumby PJ, Chisholm JRM, Edwards AJ, Clark CD, Roark EB,
Andrefouet S, Jaubert J (2001) Unprecedented bleachinginduced mortality in Porites spp. at Rangiroa Atoll, French Polynesia. Mar Biol 139:183-189

Ninio R, Meekan M, Done T, Sweatman H (2000) Temporal patterns in coral assemblages on the Great Barrier Reef from local to large spatial scales. Mar Ecol Prog Ser 194: 65-74

Palmer MW (1993) Putting things in even better order: the advantages of canonical correspondence analysis. Ecology $74: 2215-2230$

Payri C (1987) Variabilité spatiale et temporelle de la communauté de macrophytes des récifs coralliens de Moorea (Polynésie française) et contribution des algues au métabolisme du carbone de l'écosystème récifal. $\mathrm{PhD}$ thesis, Université des Sciences et Techniques du Languedoc, Montpellier

Pearson RG (1981) Recovery and recolonization of coral reefs. Mar Ecol Prog Ser 4:105-122

Pfeffer RA, Tribble GW (1985) Hurricane effect on an aquarium fish fishery in the Hawaiian Islands. Proc 5th Int Coral Reef Congr, Tahiti 3:331-336

Quinn JF, Dunham AE (1983) On hypothesis testing in ecology and evolution. Am Nat 122:602-617

Randall RH, Eldredge LG (1977) Effects of typhoon Pamela on the coral reefs of Guam. Proc 3rd Int Coral Reef Symp, Miami 2:526-531

Reese ES (1977) Coevolution of corals and coral feeding fishes of the family Chaetodontidae. Proc 3rd Int Coral Reef Symp, Miami 1:267-274

Reese ES (1981) Predation on corals by fishes of the family Chaetodontidae: implications for conservation and management of coral reef systems. Bull Mar Sci 3:594-604

Roberts CM, Shepherd ARD, Ormond RFG (1992) Large-scale variation in assemblage structure of Red Sea butterflyfishes and angelfishes. J Biogeogr 19:239-250

Rogers CS, Suchanek TH, Pecora FA (1982) Effects of hurricanes David and Frederick (1979) on shallow Acropora palmata communities: St. Croix, U.S. Virgin Islands. Bull Mar Sci 32:532-548

Rogers CS, McLain LN, Tobias CR (1991) Effects of hurricane Hugo (1989) on a coral reef in St. John. Mar Ecol Prog Ser 78:189-199

Rowan R, Knowlton N, Baker A, Jara A (1997) Landscape ecology of algal symbionts creates variation in episodes of coral bleaching. Nature 388:265-269

Sale PF, Steel WS (1989) Temporal variability in patterns of association among fish species on coral patch reefs. Mar Ecol Prog Ser 51:35-47

Salvat B (1992) Blanchissement et mortalité des scléractiniaires sur les récifs de Moorea (archipel de la Société) en 1991. CR Acad Sci Paris 314:105-111

Salvat B, Vergonzanne G, Galzin R, Richard G, Chevalier JP, Ricard M, Renaud-Mornant J (1979) Conséquences écologiques des activités d'une zone d'extraction de sable corallien dans le lagon de Moorea (île de la Société, Polynésie française). Cah Indo-Pac 1:83-126

Shinn E (1976) Coral reef recovery in Florida and the Persian Gulf. Environ Geol 1:241-254

Shulman MJ, Robertson DR (1996) Changes in the coral reefs of San Blas, Caribbean Panama: 1983 to 1990. Coral Reefs 15:231-236

Smith SR (1988) Recovery of a disturbed reef in Bermuda: influence of reef structure and herbivorous grazers on algal and sessile invertebrate recruitment. Proc 6th Int Coral Reefs Symp, Townsville 2:267-272

Sokal RR, Rohlf FJ (1995) Biometry, 3rd edn. WH Freeman, New York 
Sousa WP (1984) The role of disturbance in natural communities. Annu Rev Ecol Syst 15:353-391

Syms C (1998) Disturbance and the structure of coral reef fish communities on the reef slope. J Exp Mar Biol Ecol 230: 151-167

ter Braak CJF (1986) Canonical correspondence analysis: a new eigenvector technique for multivariate direct gradient analysis. Ecology 67:1167-1179

ter Braak CJF (1987) The analysis of vegetation-environment relationships by canonical correspondence analysis. Vegetatio 69:69-77

ter Braak CJF (1988) Partial canonical correspondence analysis. In: Block HH (ed) Classification and related methods of data analysis. North Holland Press, Amsterdam, p 551-558

ter Braak CJF (1992) CANOCO. A FORTRAN program for canonical community ordination by (partial) (detrended) (canonical) correspondence analysis, principal components analysis and redundancy analysis. Microcomputer Power, Ithaca, NY

Vigliola L, Galzin R, Harmelin-Vivien ML, Mazeas F, Salvat B (1996) Les heterocongrinae (Teleostei: Congridae) de la pente externe de Moorea (île de la Société, Polynésie

Editorial responsibility: Otto Kinne (Editor),

Oldendorf/Luhe, Germany française): distribution et biologie. Cybium 20:379-393

Williams DMcB (1986) Temporal variation in the structure of reef slope fish communities (central Great Barrier Reef): short-term effects of Acanthaster planci infestation. Mar Ecol Prog Ser 28:157-164

Williams EH, Bunkley-Williams L (1990) The worldwide coral reef bleaching cycle and related sources of coral mortality. Atoll Res Bull 335:1-71

Wilkinson CR, Lindén O, Cesar $\mathrm{H}$, Hodgson G, Rubens J, Strong AE (1999) Ecological and socioeconomic impacts of 1998 coral mortality in the Indian Ocean: an ENSO impact and a warning of future change? Ambio 28:188-196

Witman JD (1992) Physical disturbance and community structure of exposed and protected reefs: a case study from St. John, U.S. Virgin Islands. Am Zool 32:641-654

Wolanski E, Delesalle B, Dufour V, Aubanel A (1993) Modelling the fate of pollutants in the Tiahura lagoon, Moorea, French Polynesia. Proc 11th Aust Conf Coast Ocean Eng, Townsville 2:583-587

Woodley JD, Chornesky EA, Clifford PA, Jackson JBC and 16 others (1981) Hurricane Allen's impact on Jamaican coral reefs. Science 214:749-755

Submitted: February 5, 2001; Accepted: February 12, 2002 Proofs received from author(s): July 11, 2002 